\title{
STUDIES ON D-TETROSE METABOLISM
}

\section{IDENTIFICATION OF PROTECTING FACTOR AGAINST COLD INACTIVATION OF D-ERYTHRULOSE REDUCTASE FROM BEEF LIVER}

\author{
Kihachiro Uehara, Tsuyoshi Tanimoto, and Hisashi Sato ${ }^{1}$ \\ Laboratory of Biochemistry, Faculty of Pharmaceutical Sciences, \\ Osaka University, Toyonaka, Osaka
}

(Received May 31, 1974)

\begin{abstract}
During purification of D-erythrulose ruductase, the existence of a protecting factor which prevents the enzyme from cold inactivation was confirmed. The factor was purified by ion exchange and paper chromatography and was identified as $\mathrm{NADP}^{+}$by paper chromatography, paper electrophoresis, determination of the components, and spectroscopic properties.
\end{abstract}

Cold lability has been reported as a property of a number of enzymes (1-5), and protection against cold inactivation is also reported in some cold-labile enzymes.

As described in the previous paper (6), purified D-erythrulose reductase from beef liver, which catalyzes the reduction of D-erythrulose to erythritol in the presence of $\mathrm{NADH}$ as well as NADPH, is rapidly inactivated by exposure to low temperature. In this paper, we describe the presence of a substance which protects D-erythrulose reductase from the cold inactivation. The substance is tentatively designated as a "protecting factor." It has been found in the enzyme preparation during purification of the enzyme. Purification and identification of the factor have been performed.

\section{EXPERIMENTAL}

1. Materials. D-Erythrulose was prepared by isomerization of D-erythrose in pyridine as described in the previous paper (6). NADH and $\mathrm{NADP}^{+}$were obtained from the Oriental Yeast Co., Ltd. Glucose 6-phosphate dehydrogenase of bakers' yeast [EC 1.1.1.49] and D-glucose 6-phosphate (disodium salt) were purchased from the Sigma Chemical Co.

2. Assay of D-erythrulose reductase. The enzyme assay, described in detail

\footnotetext{
1 上原喜八郎, 谷本 剛, 佐藤 寿
} 
previously (6), was carried out by measuring a decrease in the absorption of NADH at $340 \mathrm{~nm}$. The assay mixture contained the enzyme and the following components in $3.0 \mathrm{ml}$ quantities: sodium phosphate buffer ( $\mathrm{pH} 6.25$ ), $250 \mu$ moles; $\mathrm{NADH}, 0.2 \mu$ mole; and D-erythrulose, $5 \mu$ moles.

3. Preparation of D-erythrulose reductase from beef liver. Acetone powder $(30 \mathrm{~g})$ of beef liver, prepared as described in the previous paper (7), was extracted with $900 \mathrm{ml}$ of water. The extract was adjusted to $\mathrm{pH} 5.8$ with $2 \mathrm{M}$ acetic acid, and centrifuged at $14,000 \times g$ for $10 \mathrm{~min}$. Alumina $\mathrm{C} \gamma$ gel $(250 \mathrm{ml}$; dry weight: $35 \mathrm{mg} / \mathrm{ml}$ ) was added to the supernatant fluid obtained above and stirred for $5 \mathrm{~min}$. The suspension was centrifuged at $14,000 \times g$ for $5 \mathrm{~min}$ and the clear supernatant fluid obtained was adjusted to $\mathrm{pH} 7.1$ with $0.1 \mathrm{M}$ dibasic sodium phosphate (fraction A-1). The supernatant fluid was heated for $7 \mathrm{~min}$ at $50^{\circ} \mathrm{C}$, immediately cooled, and centrifuged at $14,000 \times g$ for $15 \mathrm{~min}$ (fraction A-2). The supernatant was fractionated with acetone. The precipitate obtained between final concentrations of $55 \%$ and $67 \%$ was collected by centrifugation at $14,000 \times g$ for 5 min and dissolved in a minimum volume of water (fraction A-3). The resulting solution was applied to a Sephadex G-200 column $(2 \times 105 \mathrm{~cm})$ equilibrated with $2.5 \mathrm{~mm}$ sodium phosphate buffer ( $\mathrm{pH} 7.0$ ) containing $2 \mathrm{~mm}$ dithiothreitol. The enzyme was eluted with the same buffer at a flow rate of $15 \mathrm{ml}$ per hr at room temperature and fractions of $4 \mathrm{ml}$ were collected. Fractions with enzyme activity were pooled and concentrated by ultrafiltration using a collodion bag (fraction A-4).

4. Estimation of $N A D P^{+}$. Paper chromatography by the descending technique was performed on a Toyo Roshi No. $51 \mathrm{~A}, 2 \times 40 \mathrm{~cm}$, filter paper with several solvent systems: solvent 1, iso-butyric acid: $0.5 \mathrm{~N}$ ammonia (10: 6); solvent 2, $70 \%$ ethanol; solvent 3, $n$-butanol: $n$-butyric acid: $28 \%$ ammonia: water (15: 15: $1: 10)$; solvent 4, iso-propanol: saturated ammonium sulfate: $0.1 \mathrm{M}$ acetate buffer, $\mathrm{pH} 6.0$ (2: 79:16); solvent 5 , iso-propanol: $11 \mathrm{~N}$ hydrochloric acid: water $(85: 22: 18)$; solvent 6 , pyridine: water $(2: 1)$; solvent 7 , iso-propanol: $28 \%$ ammonia $(7: 3)$. Spots were detected either by the absorption of ultraviolet light or by the reaction with methylethylketone-ammonia (8), which gave a light blue fluorescence with nicotinamide derivatives.

Paper electrophoresis was conducted on a Toyo Roshi No. $51 \mathrm{~A}, 6 \times 40 \mathrm{~cm}$, filter paper at $18 \mathrm{~V} \mathrm{~cm}^{-1}$ for $50 \mathrm{~min}$ with several solvent systems: (A) $2.5 \%$ formic acid-7.8\% acetic acid (pH 1.8), (B) $0.05 \mathrm{~m}$ citrate buffer ( $\mathrm{pH} 3.0$ ), (C) $0.05 \mathrm{~m}$ acetate buffer ( $\mathrm{pH}$ 5.0), and (D) $0.05 \mathrm{M}$ borax ( $\mathrm{pH}$ 9.2). Spots were detected under ultraviolet light.

Ultraviolet absorption spectra of the sample under various conditions were taken with a Shimadzu UV-200 double-beam spectrophotometer equipped with a Shimadzu U-125MU recorder. Cyanide addition reaction was performed according to the method of CoLowick et al. (9). The determination of the total phosphate content was essentially based on the method of FISKE and SUBBARow (10) after hydrolysis of the sample in sulfuric acid-perchloric acid mixture. 
Ribose was determined by the method of Dische (11) after hydrolysis of the sample in $1 \mathrm{~N}$ hydrochloric acid at $100^{\circ} \mathrm{C}$ for $15 \mathrm{~min}$.

Enzymatic reaction of the sample was performed with glucose 6-phosphate dehydrogenase and D-glucose 6-phosphate, according to the method of Noltmann and Gubler (12).

\section{RESULTS AND DISCUSSION}

\section{Detection of the "protecting factor" in the enzyme preparations}

D-Erythrulose reductase preparations before (fraction A-3) and after (fraction A-4) Sephadex G-200 gel filtration showed quite different stability against exposure to low temperature. Fraction A-4 was unstable at low temperature and lost about $70 \%$ of its original activity after incubation of the fraction for $21 \mathrm{hr}$ at $0^{\circ} \mathrm{C}$. On the contrary, fraction A-3 retained the original activity. Both preparations were stable if the incubation temperature was raised to $22^{\circ} \mathrm{C}$ (Fig. 1). Fraction A-3 was then heated at $80^{\circ} \mathrm{C}$ for 5 min to denature proteins, and centrifuged to get a clear supernatant fluid (P-factor 1). Addition of the fluid to fraction A-4 completely protected D-erythrulose reductase from the cold inactivation (Table 1). The results indicate that, in fraction A-3, a heat stable "protecting factor" which prevented D-erythrulose reductase from the cold inactivation was present and was removed by gel filtration.

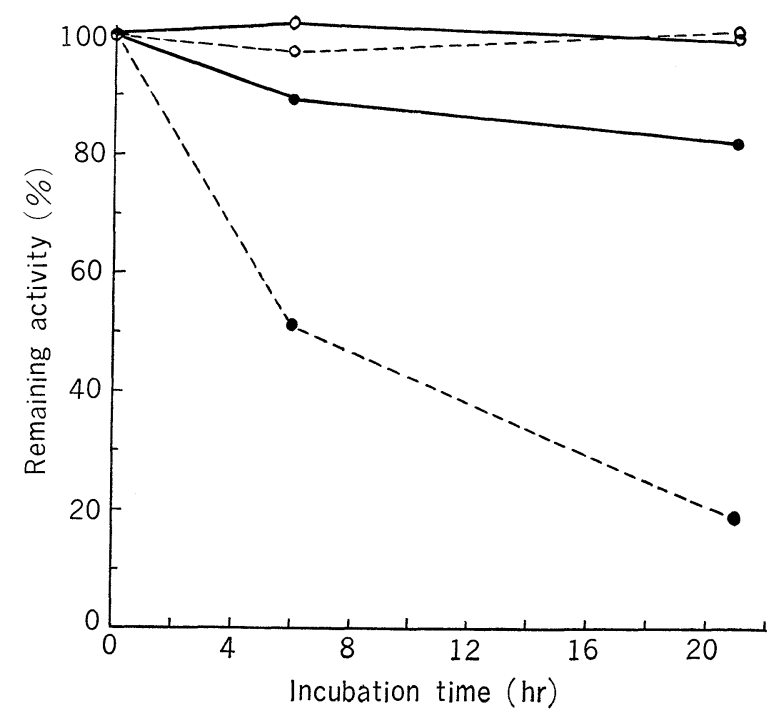

Fig. 1. Effect of temperature on stability of D-erythrulose reductase. Fraction A-3 (O) and A-4 (๑) were diluted to a concentration of $0.23 \mathrm{mg}$ and $0.17 \mathrm{mg}$ per $\mathrm{ml}$ with $2.5 \mathrm{~mm}$ phosphate buffer $(\mathrm{pH} 7.0)$, respectively, and incubated at $0^{\circ} \mathrm{C}(----)$ or $22^{\circ} \mathrm{C}$ (-). Aliquots were removed after 6 and $21 \mathrm{hr}$ and were assayed for enzyme activity. The remaining activities were expressed as a percentage of the values obtained at $0 \mathrm{hr}$ incubation for each sample. 
Table 1. Effects of P-factors 1, 2, and 3 on stability of D-erythrulose reductase.

The fraction A-4 was diluted to a concentration of $0.29 \mathrm{mg}$ per $\mathrm{ml}$ with $2.5 \mathrm{~mm}$ phosphate buffer ( $\mathrm{pH}$ 7.0). After addition of P-factors 1, 2, or 3, samples were incubated at $0^{\circ} \mathrm{C}$. Aliquots were removed at 7,21, and $31 \mathrm{hr}$ and assayed for enzyme activity. Remaining activities were expressed as a percentage of values obtained at $0 \mathrm{hr}$ incubation for each sample. The concentrations of P-factors 1, 2, and 3 were calculated from millimolar extinction coefficient of $\mathrm{NADP}^{+}, 18.0$ at $260 \mathrm{~nm}$.

\begin{tabular}{lcrrr}
\hline \multirow{2}{*}{ Addition } & $\begin{array}{c}\text { Concentration } \\
(\mathrm{mM})\end{array}$ & $7 \mathrm{hr}$ & $21 \mathrm{hr}$ & $31 \mathrm{hr}$ \\
\cline { 3 - 5 } & & 62 & 34 & 17 \\
None & 14 & 108 & 111 & 109 \\
P-factor 1 & 12 & 104 & 100 & 103 \\
P-factor 2 & 2.3 & 100 & 95 & 91 \\
& 0.15 & 104 & 109 & 107 \\
P-factor 3 & 0.02 & 100 & 99 & 104 \\
& & & & \\
\hline
\end{tabular}

\section{Characterization of the "protecting factor" present in fraction $A-3$}

Isolation of the "protecting factor" was performed as follows. Thirty milliliters of fraction A-3 was heated at $80^{\circ} \mathrm{C}$ for $5 \mathrm{~min}$, and supernatant fluid (P-factor 1) obtained by centrifugation at $14,000 \times g$ for $15 \mathrm{~min}$ was applied to a Dowex $1 \times 2$ (formate form) column $(1 \times 8 \mathrm{~cm})$. After the column was washed with $60 \mathrm{ml}$ of water, elution was carried out with a linear concentration gradient formed with $140 \mathrm{ml}$ of water in the mixing chamber and an equal volume of $4 \mathrm{~N}$ formic acid in the reservoir. Fractions of $6 \mathrm{ml}$ were collected and the progress

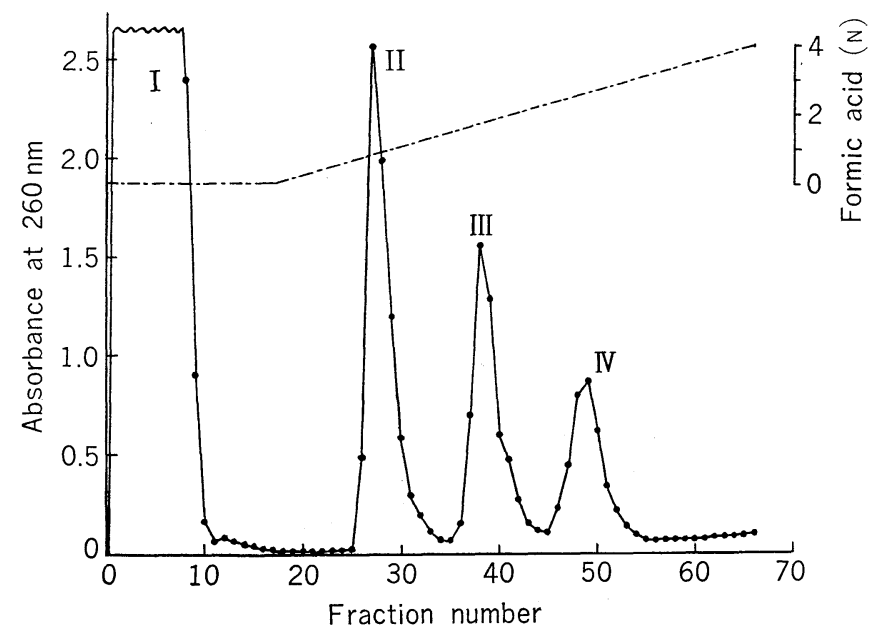

Fig. 2. Dowex $1 \times 2$ (formate) column chromatography of P-factor 1 . The experimental conditions are as described in the text. - - , absorbance at $260 \mathrm{~nm} ;-\cdot-\cdot$, concentration of formic acid. 
of the elution was followed by measuring the absorbance at $260 \mathrm{~nm}$. A typical elution pattern is shown in Fig. 2.

Peak III in Fig. 2 corresponded to the "protecting factor." The fractions of tubes numbered 37-42 were combined and extracted eight times with $70 \mathrm{ml}$ of ether to remove the formic acid. The ethereal extracts were discarded and the aqueous solution was lyophilized. The light yellow residue was dissolved in $0.5 \mathrm{ml}$ of water (P-factor 2). P-factor 2 was chromatographed successively on paper with solvents 1 and 2 . The part with the "protecting factor" was cut into strips and extracted with $30 \mathrm{ml}$ of water. The aqueous extract was concentrated by evaporation in vacuo at $30^{\circ} \mathrm{C}$. The white residue was dissolved in $3 \mathrm{ml}$ of water $(\mathrm{P}-$ factor 3).

P-factor 3 afforded complete protection against the cold inactivation of Derythrulose reductase (Table 1).

Table 2. $R f$ values of P-factor 3 on paper chromatograms.

The solvent systems and the experimental conditions are as described in the text.

\begin{tabular}{ccc}
\hline \multirow{2}{*}{ Solvent system } & \multicolumn{2}{c}{$R f$ values } \\
\cline { 2 - 3 } & P-factor 3 & NADP $^{+}$ \\
\hline Solvent 3 & 0.02 & 0.02 \\
Solvent 4 & 0.48 & 0.49 \\
Solvent 5 & 0.30 & 0.30 \\
Solvent 6 & 0.63 & 0.62 \\
Solvent 7 & 0.16 & 0.16 \\
\hline
\end{tabular}

(A)

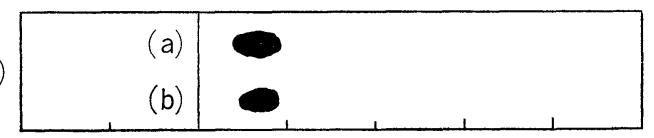

(B)

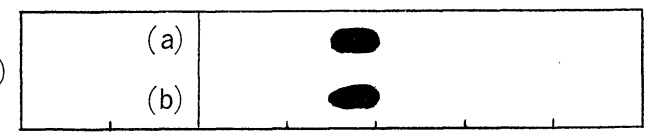

(C)
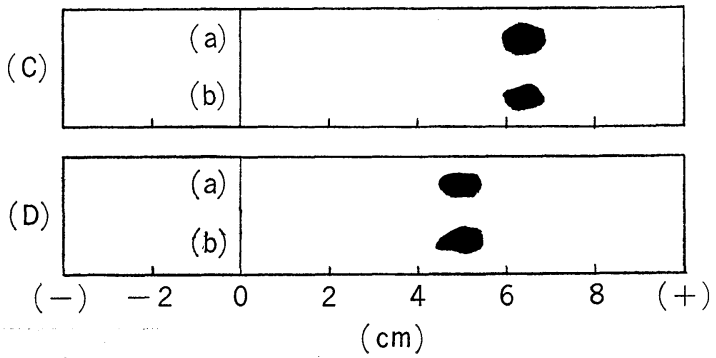

Fig. 3. Paper electrophoresis of P-factor 3 and $\mathrm{NADP}^{+}$. The experimental conditions are as described in the text. Solvent system: (A) $2.5 \%$ formic acid-7.8\% acetic acid (pH 1.8); (B) $0.05 \mathrm{M}$ citrate buffer ( $\mathrm{pH} 3.0$ ); (C) $0.05 \mathrm{M}$ acetate buffer ( $\mathrm{pH} 5.0$ ); (D) $0.05 \mathrm{M}$ borax (pH 9.2). (a), $\mathrm{NADP}^{+}$; (b), P-factor 3 . 
The P-factor gave a single spot on paper chromatography and paper electrophoresis in various solvent systems, and the $R f$ values and the mobilities agreed well with those of authentic NADP ${ }^{+}$in all cases, as shown in Table 2 and Fig. 3.

Table 3 shows the determination of phosphate, ribose, and nicotinamide riboside contents in P-factor 3. These results demonstrate that P-factor 3 has the same composition as that of $\mathrm{NADP}^{+}$.

Table 3. Composition of P-factor 3.

\begin{tabular}{lc}
\hline \multicolumn{1}{c}{ Composition } & moles/mole \\
\hline Oxidized form $^{a}$ & 1.00 \\
Nicotinamide riboside $^{b}$ & 0.97 \\
Phosphate $_{\text {Ribose }}$ & 2.95 \\
& 2.08 \\
\hline
\end{tabular}

a Determined by measuring the absorption at $260 \mathrm{~nm}$ with a millimolar extinction coefficient of 18.0 for $\mathrm{NADP}^{+}$.

$b$ Calculated from the absorbance at $327 \mathrm{~nm}$ in $1 \mathrm{M}$ potassium cyanide with a millimolar extinction coefficient of 6.3 .

Fig. 4 shows the ultraviolet absorption spectra of P-factor 3 and $\mathrm{NADP}^{+}$in neutral and in acidic solutions. Both of the compounds had an absorption maximum at $260 \mathrm{~nm}$ in water, and at $258 \mathrm{~nm}$ in $1 \mathrm{~N}$ hydrochloric acid. When potassium cyanide was added to P-factor 3 to a concentration of $1 \mathrm{M}$, a new absorption spectrum with an absorption maximum at $327 \mathrm{~nm}$ appeared, which was typical of nicotinamide riboside-cyanide complex (9) (Fig. 5). These spectral characteristics of P-factor 3 were identical with those of authentic NADP ${ }^{+}$.

In the presence of D-glucose 6-phosphate and glucose 6-phosphate dehydrogenase, $\mathrm{P}$-factor 3 and $\mathrm{NADP}^{+}$showed the same spectral change at equal rate.

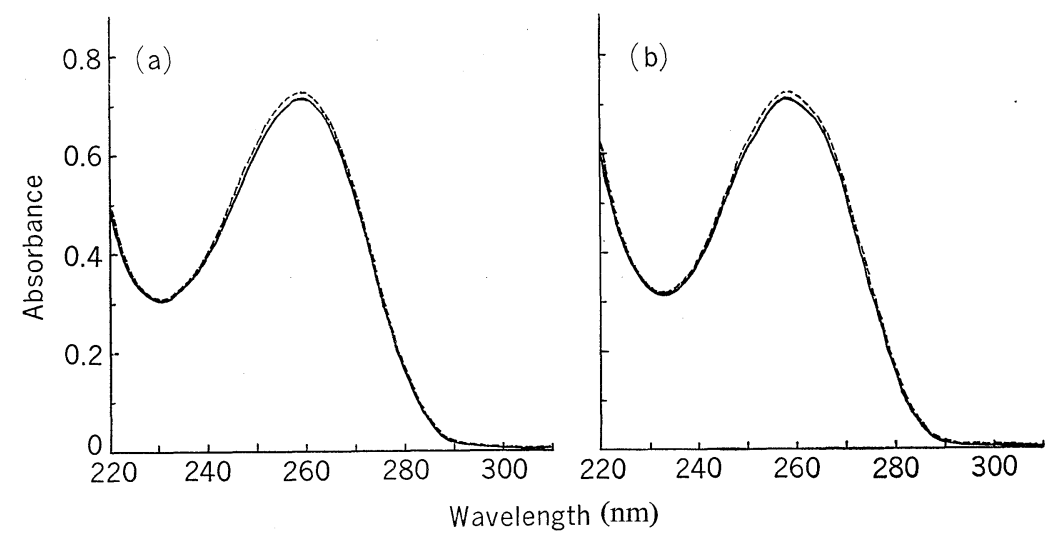

Fig. 4. Ultraviolet absorption spectra of P-factor 3 and $\mathrm{NADP}^{+}$. (a) Spectra in water.

(b) Spectra in $1 \mathrm{~N}$ hydrochloric acid. - P-factor $3 ;-----, \mathrm{NADP}^{+}$. 
The final spectrum was found to be identical with that of $\mathrm{NADP}^{+}$(Fig. 6).

From the results described above, it is obvious that the "protecting factor" present in the enzyme preparation (fraction A-3) is NADP ${ }^{+}$.

Since $\mathrm{NADP}^{+}$exists in D-erythrulose reductase and prevents the enzyme from

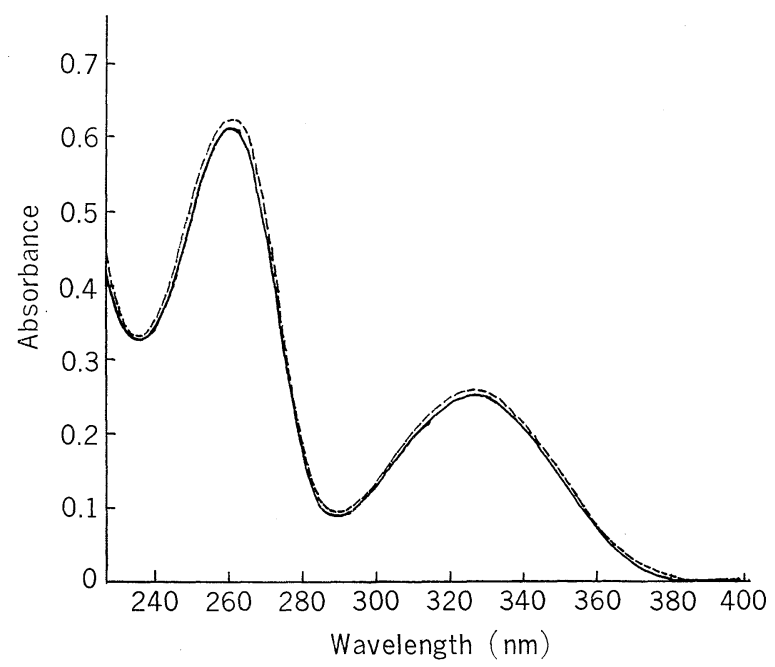

Fig. 5. Effect of cyanide on the absorption spectra of P-factor 3 and $\mathrm{NADP}^{+}$

P-factor, $30 \mathrm{~min}$ after addition of $1 \mathrm{M}$ cyanide; ------, $\mathrm{NADP}^{+}, 30 \mathrm{~min}$ after addition of 1 M cyanide.

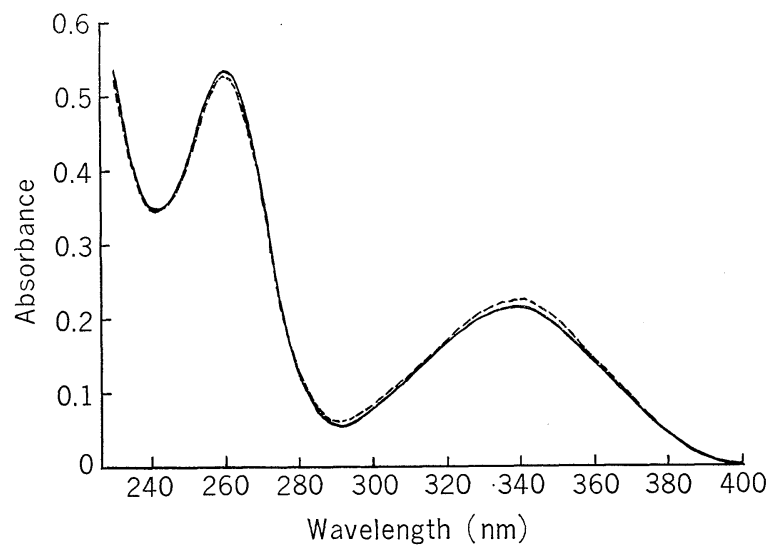

Fig. 6. Reduction of P-factor 3 by glucose 6-phosphate dehydrogenase of bakers' yeast. To $0.1 \mathrm{ml}$ of P-factor 3 or $1 \mathrm{mM} \mathrm{NADP}{ }^{+}, 0.1 \mathrm{ml}$ of glucose 6-phosphate dehydrogenase, $2.5 \mathrm{ml}$ of $0.1 \mathrm{M}$ glycylglycine buffer $\left(\mathrm{pH} 8.0\right.$ ) and $0.2 \mathrm{ml}$ of $0.15 \mathrm{mM} \mathrm{MgCl}_{2}$ were added. The reaction was started by addition of $0.1 \mathrm{ml}$ of $0.03 \mathrm{M} \mathrm{D}$-glucose 6phosphate. After the reaction was completed, absorption spectra of the reaction mixtures were recorded. —_, P-factor $3 ;$-..--, $\mathrm{NADP}^{+}$. 
cold inactivation as described in this paper, we conclude that $\mathrm{NADP}^{+}$plays a very important role for in the regulation of the enzyme.

A study of the protective mechanism of $\mathrm{NADP}^{+}$to cold inactivation is now in progress.

\section{REFERENCES}

1) Jarabak, J., Seeds, A. E., Jr., and Talalay, P., Biochemistry, 5, 1269 (1966).

2) Irtas, J. J., Olmsted, M. R., and Utter, M. F., Biochemistry, 8, 5136 (1969).

3) Feldberg, R. S. and Datta, P., Eur. J. Biochem., 21, 447 (1971).

4) Brown, M. S., Dana, S. E., Dietschy, J. M., and Siperstein, M. D., J. Biol. Chem., 248, 4731 (1973).

5) Kono, N. and Uyeda, K., J. Biol. Chem., 248, 8603 (1973).

6) Uehara, K., Tanimoto, T., and Sato, H., J. Biochem., 75, 333 (1974).

7) Uehara, K., Sugeno, K., and Muzoguchi, T., J. Vitaminol., 9, 206 (1963).

8) Kodicek, E. and Reddi, F. F., Nature, 168, 475 (1951).

9) Colowick, S. P., Kaplan, N. O., and Ciotti, M. M., J. Biol. Chem., 191, 447 (1951).

10) Fiske, C. H. and SubbaRow, Y., J. Biol. Chem., 66, 375 (1925).

11) DisCHe, Z., J. Biol. Chem., 204, 983 (1953).

12) Noltmann, E. A. and Gubler, C. J., J. Biol. Chem., 236, 1225 (1961). 